\title{
Konsep Ekonomi Pada Masa Dinasti
}

\author{
Rezki Amalia Fathurrahman (90100118108) \\ Email:rezkiamalia56@gmail.com
}

\begin{abstract}
Abstrak
Konsep ekonomi pada masa dinasti ini, dimulai dari dinasti Umayyah yang dimana para khalifah menerapkan konsep ekonomi Islam yang pertama khalifah Muawiyah bin Abu Sufyan yang dimana beliau pernah menerapkan beberapa kebijakan ekonomi yaitu, pernah membangun kantor catatan negara dan layanan pos, membangun kekuatan militer dan pemberian gaji tetap, mengembangkan Qadi atau hakim secara professional, membangun birokrasi (pajak dan administrasi public). Khalifah kedua, Abdul Malik bin Marwan yang dimana beliau pernah menerapkan beberapa kebijakan ekonomi yaitu, mencetak uang sendiri, Hukuman Ta'zir atau memberikan sanksi kepada yang melanggar aturan pemerintah, pembenahan administrasi, khalifah terakhir Umar bin Abdul Aziz yang dimana beliau pernah membuat kebijakan ekonomi yang pertama, memgembalikan harta pribadi dan keluarga kepada Baitul Maal, memprioritaskan pembangunan dalam negeri, menghapus pajak bagi kaum muslim dan mengurangi beban pajak nasrani dan membasmi kerja paksa, menetapkan gaji pejabat dan dilarang memiliki kerja sampingan. Dinasti Abbasiyah yang dimana dinasti pernah menerapkan beberapa kebijakan ekonomi yang pertama khalifah Abu Jafar Al-Manshur pernah menerapkan kebijakan untuk menertibkan administrasi birokrasi, bersikap keras terhadap kedudukan keuangan negara, hemat dalam membelanjakan uang negara, khalifah selanjutnya Harun Al-Rasyid dimana beliau menerapkan kebijakan, diversifikasi sumber pendapatan negara, berfokus pada perpajakan (AlMuhassabah, Al-Mussaqamah, Al-Muqqath'ah. Terakhir dinasti masa Ustmani dimana kebijakannya ini menerapkan desentralisasi pengaturan pajak, kebijakan dalam bidang pertanian dan melakukan efisiensi pengeluaran.
\end{abstract}

Kata Kunci: Pajak, Birokrasi pajak pertanian 


\section{Pendahuluan}

Konsep ekonomi dinasti bani Umayyah pernah menerapkan beberapa kebijakan ekonomi. Khalifah pertama Muawiyah bin Abu Sufyan kebijakan yang dilakukan beliau membangun masyarakat muslim tertata dengan rapi yang dimana merupakan syarat kondusifnya suatu ekonomi, membangun kantor catatan negara dan layanan pas pertama dalam Islam. Membangun pasukan damaskus menjadi kekuatan militer dan memberikan gaji tetap, mencetak uang dan membangun birokrasi seperti mengumpulkan pajak dan administrasi politik, mengembangan jabatan qadi (hakim) yang professional. Khalifah kedua Abdul Malik bin Marwan dimana beliau pernah membuat kebijakan seperti mencetak uang sendiri setelah pihak romawi menolak untuk membuat mata uang dengan Bismillahirrahmanirrahim dan beliau sempat menghapusnya tetapi beliau kembali mencantumkan mata uang basmalah dengan mencetak uang sendiri, menjatuhkan hukuman ta'zir kepada mereka yang ingin mencetak uang di luar percetakan negara, melakukan pembenahan administrasi pemerintah misalnya pajak dan menggunakan bahasa Arab sebagai bahasa resmi dalam adminitrasi pemerintahan. Khalifah ketiga Umar bin Abdul Aziz dalam kebijakannya beliau pernah mengumpulkan rakyat dan mengembalikan seluruh harta kekayaan pribadi dan keluarga kepada pemiliknya masing-masing, beliau tidak mengambil sepeserpun dari Baitul Maa termasuk pendapatan fa'i yang seharusnya menjadi haknya, mementingkan pembangunan dalam negeri dibandingkan melakukan ekspansi wilayah, melindungi dan meningkatkan taraf hidup masyarakat secara keseluruhan, menghapus pajak terhadap muslim dan mengurangi beban pajak non muslim serta tidak melakukan 
kerja paksa, memperbaiki tanah pertanian, membuat sumur, pembangunan jalan, membangun tempat penginapan untuk musafir dan menyantuni fakir miskin, menetapkan gaji sebesar 300 dirham dan dilarang melakukan kerja sampingan.(Dewi Indasari 2017)

Dinasti Abbasiyah dimana pada masa ini merupakan puncak kejayaan Islam dan pusat pemerintahan dan peradaban Islam. Khalifah pertama Abdullah AlSaffah meletakkan landasan perkembangan filsafat dan pengetahuan Islam dan masa kepemimpinannya pun bisa dibilang sebentar maka dari yang melanjutkan pemerintahan untuk selanjutnya adalah khalifah kedua, Al-Manshur dimana beliau melakukan konsolidasi dan penertiban administrasi birokrasi selain itu memindahkan pusat pemerintah yang semula di Hasyimiyah pindah kekota Baghdad, pada awalnya pemerintahan perbendaharaan negara dikatakan tidak ada karena pada masa khalifah sebelumnya al-Saffah menggunakan dana Baitul Maal untuk diberikan kepada para sahabat dan tentara demi mempertahankan kekuasaannya sehingga hal tersebut mendorong beliau untuk bertindak keras dalam mempertahankan kedudukan keuangan negara, dan sangat hemat dalam membelanjakan uang negara.(Muhammad Nurul Huda 2020)

Dinasti bani Utsmani, pada masa ini Turki Utsmani terkenal dengan kemampuannya di bidang militer dan politik sehingga perekonomiannya pun meningkat tetapi masalahnya terkadang terjadi peperangan yang berkesinambungan khususnya melakukan perluasan wilayah ataupun meredakan ketegangan dalam negeri yang dimana dalam perang tersebut menguras sumber 
dana turki ustmani yang cukup besar. Karena peperangan yang dilakukan terus berlanjut menyebabkan pendapatan negara berkurang sementara belanja negara terus meningkat. Maka dari itu kenapa turki ustmani menerapkan kebijakan desentralisasi pengaturan pajak karena sibuk mengurusi perang sehingga menyerahkan kebijakan pajak ini kepada daerah untuk mengumpulkan sumber pendapatan dan tidak perlu diserahkan kepada pusat pemerintah cukup daerah saja yang mengelolanya.(Mami Nofrianti dan Kori Lilie Muslim 2019) 


\section{Pembahasan}

Konsep ekonomi dinasti bani Umayyah pernah menerapkan beberapa kebijakan ekonomi. Khalifah pertama Muawiyah bin Abu Sufyan kebijakan yang dilakukan beliau membangun masyarakat muslim tertata dengan rapi yang dimana merupakan syarat kondusifnya suatu ekonomi, membangun kantor catatan negara dan layanan pas pertama dalam Islam. Membangun pasukan damaskus menjadi kekuatan militer dan memberikan gaji tetap, mencetak uang dan membangun birokrasi seperti mengumpulkan pajak dan administrasi politik, mengembangan jabatan qadi (hakim) yang professional. Khalifah kedua Abdul Malik bin Marwan dimana beliau pernah membuat kebijakan seperti mencetak uang sendiri setelah pihak romawi menolak untuk membuat mata uang dengan Bismillahirrahmanirrahim dan beliau sempat menghapusnya tetapi beliau kembali mencantumkan mata uang basmalah dengan mencetak uang sendiri, menjatuhkan hukuman ta'zir kepada mereka yang ingin mencetak uang di luar percetakan negara atau melanggar aturan dari pemerintahan, melakukan pembenahan administrasi pemerintah misalnya pengumpulan pajak dan menggunakan bahasa Arab sebagai bahasa resmi dalam adminitrasi pemerintahan.(Dewi Indasari 2017) Khalifah terakhir, Umar bin Abdul Aziz yang dimana kebijakannya ini menggunakan konsep welfare state atau negara sejahtera karena beliau ingin mengubah dan menerapkan kebijakan ini kearah yang lebih produktif untuk kesejahteraan masyarakat alasan beliau menerapkan kebijakan ini ialah adanya ketimpangan ekonomi atau pendapatan yang sangat tidak adil antara kaum kelas atas dan kelas bawah sehingga beliau ingin menyetarakan pendapat masyarakat bahwa semuanya berhak untuk 
sejahtera dan bahagia.(Annisa Silvi Kusumastuti dan Mohammad Ghozali 2019) selain itu beliau tidak mengambil sepeserpun dari Baitul Maa termasuk pendapatan fa'i yang seharusnya menjadi haknya, mementingkan pembangunan dalam negeri dibandingkan melakukan ekspansi wilayah, melindungi dan meningkatkan taraf hidup masyarakat secara keseluruhan, menghapus pajak terhadap muslim dan mengurangi beban pajak non muslim serta tidak melakukan kerja paksa, memperbaiki tanah pertanian, membuat sumur, pembangunan jalan, membangun tempat penginapan untuk musafir dan menyantuni fakir miskin, menetapkan gaji sebesar 300 dirham dan dilarang melakukan kerja sampingan.(Dewi Indasari 2017)

Dinasti Abbasiyah dimana pada masa ini merupakan puncak kejayaan Islam dan pusat pemerintahan dan peradaban Islam. Khalifah pertama Abdullah AlSaffah meletakkan landasan perkembangan filsafat dan pengetahuan Islam dan masa kepemimpinannya pun bisa dibilang sebentar maka dari yang melanjutkan pemerintahan untuk selanjutnya adalah khalifah kedua, Al-Manshur dimana beliau melakukan konsolidasi dan penertiban administrasi birokrasi selain itu memindahkan pusat pemerintah yang semula di Hasyimiyah pindah kekota Baghdad, pada awalnya pemerintahan perbendaharaan negara dikatakan tidak ada karena pada masa khalifah sebelumnya al-Saffah menggunakan dana Baitul Maal untuk diberikan kepada para sahabat dan tentara demi mempertahankan kekuasaannya sehingga hal tersebut mendorong beliau untuk bertindak keras dalam mempertahankan kedudukan keuangan negara, dan sangat hemat dalam membelanjakan uang negara. Karena keberhasilan beliau meletakkan dasar-dasar pemerintahan bani Abbasiyah memudahkan khalifah selanjutnya untuk untuk fokus 
di masalah perekonomian dan keuangan negara khalifah selanjutnya al-Mahdi dimasa pemerintahannya keadaan negara stabil. Dan kebijakan ini menguntungkan rakyat dimana pernah membangun penginapan untuk musafir haji, membuat kolam bagi kafilah, menigkatkan sektor pertanian seperti emas, perak tembaga, dan logam bahkan membaut jalur perdagangan antara Timur dan Barat selain itu beliau mengembalikan harta yang pernah di rampas ayahnya kepada pemiliknya masingmasing. Khalifah Harun Al- Rasyid dimana beliau pernah membuat kebijakan seperti mendiversifikasi sumber pendapatan negara, membangun Baitul Maal untuk mengurus keuangan negara sehingga menunjuk seorang wajiz sebagai kepala beberapa diwan misalnya diwan al-khazanah tugasnya mengurus seluruh perbendaharaan negara, diwan al- azra bertugas mengurus kekayaan negara berupa hasil bumi, diwan khazain al-silah bertugas mengurus perlengkapan angkatan perang terakhir pengumpulan sumber pendapatan negara seperti kharaj, jizyah, zakat fai, ghanimah, ushr dan harta lainnya. Selain itu beliau juga sangat fokus terhadap pajak sehingga menunjuk Abu Yusuf untuk mengelola pajak dan membuat kitab pedoman pajak yang berjudul Al-Kharaj yang sistem pemungutan terbagi atas tiga yaitu, al-muhassabah pajak dibayar tergantung jumlah luas area tanah, almussaqamah menetapkan jumlah presentase dari hasil pendapatan yang diperoleh dan terakhir al-muqqatha'ah menetapkan hasil pajak bumi kepada orang-orang kaya sesuai dengan kesepakatan pemerintah dan orang yang bersangkutan. Setelah beliau wafat dilanjutkan oleh anaknya al-ma'mum yang dimana beliau sangat menyukai ilmu pengetahuan sehingga beliau mengalokasi dana Baitul Maal untuk membayar penerjemah dan mendirikan sekolah dan perguruan tinggi. Dan beliau membangun 
lembaga pendidikan yang bernama Baitul Hikmah sebagai pusat penerjemah bagi perguruan tinggi dan merupakan perpustakaan yang besar. Pada masa itu Baghdad merupakan pusat kebudayaan Islam termasuk perekonomian. Tetapi dinasti tidak begitu lama karena kemunduran dan di hancurkan oleh kaum Monggol.(Muhammad Nurul Huda 2020)

Dinasti Utsmani, dimana turki ustmani ini pernah menerapkan beberapa kebijakan seperti menerapkan desentralisasi pengaturan pajak, kebijakan dalam bidang pertanian dan melakukan efisiensi pengeluaran. Tetapi permasalahannya terkadang terjadi peperangan yang berkesinambungan khususnya melakukan perluasan wilayah ataupun meredakan ketegangan dalam negeri yang dimana dalam perang tersebut menguras sumber dana turki ustmani yang cukup besar. Karena peperangan yang dilakukan terus berlanjut menyebabkan pendapatan negara berkurang sementara belanja negara terus meningkat. Maka dari itu kenapa turki ustmani menerapkan kebijakan desentralisasi pengaturan pajak karena sibuk mengurusi perang sehingga menyerahkan kebijakan pajak ini kepada daerah untuk mengumpulkan sumber pendapatan dan tidak perlu diserahkan kepada pusat pemerintah cukup daerah saja yang mengelolanya.(Mami Nofrianti dan Kori Lilie Muslim 2019) 


\section{Kesimpulan}

Bahwa di setiap periode kepemimpinan pernah mencapai puncak kejayaan terutama dalam hal perekonomian misalnya pada dinasti Umayyah pernah mencapai keemasan di mana khalifah pernah menerapkan beberapa kebijakan seperti khalifah Muawiyah bin Abu Sufyan pernah menerapkan kebijakan membangun kantor catatan negara dan layanan pos pertama dalam Islam, mencetak uang, membangun birokasi, dan memberikan gaji tetap untuk militer. Khalifah Abdul Malik bin Marwan pernah membuat suatu kebijakan yaitu mencetak uang sendiri dengan bismillahirrahmanirrahim setelah mendapatkan penolakan dari pihak Romawi sehingga beliau berinisiatif membuat uang sendiri. Khalifah terakhir Umar bin Abdul Aziz pernah menerapkan kebijakan menggunakan konsep welfare state atau negara sejahtera karena beliau ingin mengubah dan menerapkan kebijakan ini kearah yang lebih produktif untuk kesejahteraan masyarakat alasan beliau menerapkan kebijakan ini ialah adanya ketimpangan ekonomi atau pendapatan yang sangat tidak adil antara kaum kelas atas dan kelas bawah. Dinasti Abbasiyah yang dimana pada masanya mencapai masa kejayaan misalnya almanshur meletak dasar-dasar pemerintahan sehingga memudahkan khalifah selanjutnya untuk lebih fokus di permasalahan ekonomi dan keuangan negara dan khalifah Harun Al-Rasyid memberikan sumbangan pemikiran ekonominya dengan mendiversifikasikan sumber pendapatan negara dan membuat kebijakan pajak yang dibantu oleh Abu Yusuf untuk membuat pedoman pembayaran pajak yang kitabnya berjudul Al-Kharaj. Dinasti terakhir Turki Utsmani dimana membuat kebijakan ekonomi menerapkan desentralisasi pengaturan pajak, kebijakan dalam bidang 
pertanian dan melakukan efisiensi pengeluaran. Tetapi permasalahanya terjadinya peperangan yang terjadi sehingga menguras sumber pendapatan negara cukup besar sedangkan belanja negara terus meningkat hingga menerapkan kebijakan desentralisasi pengaturan pajak karena sibuk mengurusi perang sehingga menyerahkan kebijakan pajak ini kepada daerah untuk mengumpulkan sumber pendapatan dan tidak perlu diserahkan kepada pusat pemerintah cukup daerah saja yang mengelolanya. 


\section{Daftar Pustaka}

Annisa Silvi Kusumastuti dan Mohammad Ghozali. 2019. "Konsep Welfare State Pada Kebijakan Umar Bin Abdul Aziz Sebagai Khalifah Bani Umayyah.” Laa Maisyir 6(2):282-96.

Dewi Indasari. 2017. "Perkembangan Pemikiran Ekonomi Islam Pada Masa Bani Umayyah.” Jurnal Ilmu Pengetahuan Teknologi \& Seni 9(2):55-60.

Mami Nofrianti dan Kori Lilie Muslim. 2019. "Kemajuan Islam Pada Masa Kekaisaran Turki Utsmani." FUADUNA:Jurnal Kajian Keagamaan Dan Kemasyarakatan 3(1):22-32.

Muhammad Nurul Huda. 2020. "Sejarah Pemikiran Ekonomi Islam Pada Masa Daulah Bani Umayyah Dan Bani Abbasiyah.”Estoria 1(01):94-105. 